\title{
PENGUATAN KEBIJAKAN PUBLIK USAHA PENGENTASAN KEMISKINAN MELALUI PENGEMBANGAN INDUSTRI MIKRO OLAHRAGA*
}

\author{
Agus Kristiyanto \\ Jurusan POK FKIP Universitas Sebelas Maret Surakarta \\ Jalan Menteri Supeno 13 Manahan Surakarta
}

Diterima 9 April 2011 / Disetujui 20 Oktober 2011

\begin{abstract}
The research aims to describe a factual account of the various responses of actual perpetrators of the real sector micro-sports industry. Dimensions are expressed related to the growth of the business climate has been done by Government and Local Government, especially for poverty alleviation through the sports industry. Conclusions: Satisfaction micro business sports industry on the performance of Local Government on eight dimensions varied business climate, sports industry in fact just giving a side job for some people, but has not been a big impact for poverty reduction. Business expectations: to contribute to alleviating poverty, the sports industry business developed specifically for quality, Social protection and security should be given to the perpetrators of the sports industry business, clear policy regarding the development of micro industries important sport once to strengthen the real sector, technical assistance by the government is required by the real sector of the sports industry.
\end{abstract}

Keywords: public policy, poverty alleviation, micro industries, sports industry

\begin{abstract}
Abstrak: Penelitian ini bertujuan mendeskripsikan secara faktual tentang berbagai respon aktual para pelaku sektor riil industri mikro olahraga. Dimensi yang diungkap berkaitan dengan penumbuhan iklim usaha yang selama ini dilakukan oleh pemerintah maupun pemerintah daerah, terutama untuk pengentasan kemiskinan melalui industri olahraga. Kesimpulannya; kepuasan pelaku usaha mikro industri olahraga terhadap kinerja pemerintah daerah atas delapan dimensi iklim usaha bervariasi; industri olahraga secara faktual sekedar memberikan lapangan pekerjaan sampingan bagi sebagian masyarakat, namun belum berdampak secara besar bagi pengentasan kemiskinan. Harapan pelaku usaha adalah turut mengentaskan kemiskinan, usaha industri olahraga dikembangkan secara khusus agar berkualitas; perlindungan sosial dan rasa aman perlu diberikan kepada para pelaku usaha industri olahraga; kebijakan yang jelas tentang pengembangan industri mikro olahraga penting sekali untuk memperkuat sektor riil; bantuan teknis oleh pemerintah sangat diperlukan oleh sektor riil industri olahraga.
\end{abstract}

Kata kunci: kebijakan publik, pengentasan kemiskinan, usaha mikro, industri olahraga

\section{PENDAHULUAN}

Dalam penjelasan Undang-undang Republik Indonesia Nomor 20 Tahun 2008 tentang Usaha Mikro, Kecil, dan Menengah, (2008: 30-31) telah

Penelitian Dana Kompetisi Hibah Strategis Nasional 2009, Surat Persetujuan Direktur Jenderal Pendidikan Tinggi Nomor 231/D3/PL/2009, tanggal 24 Maret 2009 diuraikan bahwa Usaha Mikro, Kecil dan Menengah merupakan kegiatan usaha yang mampu memperluas lapangan kerja dan memberikan pelayanan ekonomi secara luas kepada masyarakat, dan dapat berperan dalam proses pemerataan dan peningkatan pendapatan masyarakat, mendorong pertumbuhan ekonomi dan berperan dalam mewujudkan stabilitas nasio- 
nal. Namun demikian Usaha Mikro, Kecil dan Menengah masih menghadapai berbagai hambatan dan kendala, terutama dalam hal produksi dan pengolahan, pemasaran, sumber daya manusia, desain dan teknologi, permodalan, serta iklim usaha.

Kendala dan hambatan tersebut tentu saja juga dirasakan pada pelaku usaha industri olahraga, yang pada umumnya "bermain" di segmen usaha mikro. Kemajuan industri mikro olahraga memiliki nilai strategis karena terkait dengan upaya pemberdayaan ekonomi rakyat kecil dan merupakan bagian dari upaya pengentasan kemiskinan. Iklim usaha yang kondusif di sektor industri olahraga juga menjadi indikator bahwa pembangunan olahraga sebenarnya memiliki dampak pengiring yang sangat luas. Dampak tersebut tidak sekadar dibatasi pada komunitas olahraga, tetapi juga pada masyarakat secara luas, terkait dengan persoalan kesejahteraan sosial.

Sesuai dengan Amanat Ketetapan Majelis Permusyawaratan Republik Indonesia Nomor XVI/MPR-RI/1998 tentang Politik Ekonomi dalam rangka Demokrasi Ekonomi, Usaha Mikro, Kecil, dan Menengah (UKM) perlu diberdayakan sebagai bagian integral ekonomi rakyat yang mempunyai kedudukan, peran, dan potensi strategis untuk mewujudkan struktur perkonomian nasional yang makin seimbang, berkembang, dan berkeadilan (Mukadimah UU-UKM, 2008:5).

UKM perlu diselenggarakan secara menyeluruh, optimal, dan berkesinambungan melalui pengembangan iklim yang kondusif, pemberian kesempatan berusaha, dukungan, perlindungan dan pengembangan usaha seluas-luasnya, sehingga mampu meningkatkan kedudukan, peran dan potensi UKM dalam mewujudkan pertumbuhan ekonomi, pemerataan, dan peningkatan pendapatan rakyat, penciptaan lapangan pekerjaan, dan pengentasan kemiskinan.

Kaitan olahraga dan pembangunan terungkap dalam Konferensi Internasional mengenai Olahraga dan Pembangunan yang digelar pada tahun 2003 di Switzerland, yang intinya membicarakan kontribusi olahraga terhadap pembangunan ekonomi, politik, sosial dan kesehatan yang dikenal dengan The Magglingen Declaration. Semangat declaration ini sejalan dengan tujuan dasar olah raga: meningkatkan kualitas hidup manusia yang berujung pada harkat dan martabat kemanusiaan. Disisi lain perkembangan dan kemajuan pembangunan olahraga tidak hanya semata-semata untuk meraih prestasi olahraga akan tetapi juga diperlukan daya dukung lain yang bisa dikembangkan melalui pembangunan dan pengembangan industri-industri olahraga.

Perkembangan yang tidak terhindarkan tersebut telah menstimulasi berbagai aktivitas keolahragaan dari ruang lingkup olahraga pendidikan, olahraga rekreasi dan olahraga prestasi menjadi sebuah event yang berorientasi tidak hanya pada tujuan lingkupnya, tetapi juga dalam dimensi industri. Untuk itu, pengamatan dan pencermatan terhadap aspek-aspek penting dalam industri olahraga menjadi bagian penting dalam menentukan kebijakan pembangunan olahraga ke depan.

Pada Bagian Penjelasan Umum atas Undang-Undang Republik Indonesia Nomor 3 Tahun 2005 Tentang Sistem Keolahragaan Nasional, ditegaskan bahwa: "keterbatasan sumber pendanaan merupakan permasalahan khusus dalam kegiatan keolahragaan di Indonesia. Hal ini semakin terasa dengan perkembangan olahraga modern yang menuntut pengelolaan, pembinaan dan pengembangan keolahragaan didukung oleh anggaran yang memadai. Kebijakan tentang sistem pengalokasian dana di dalam Anggaran Pendapatan dan Belanja Negara dan Anggaran Pendapatan dan Belanja Daerah dalam bidang keolahragaan sesuai dengan kemampuan anggaran harus dilaksanakan agar pembinaan dan pengembangan keolahragaan nasional dapat berjalan lancar. Selain itu, sumber daya dari masyarakat perlu dioptimalkan, antara lain melalui peran serta masyarakat dalam pengadaan dana, pengadaan/pemeliharaan prasarana dan sarana, dan dalam industri olahraga".

Rintisan dan pengembangan industri olahraga di Indonesia bukan sesuatu yang baru. Namun keberadaan industri olahraga tersebut baru sebatas pada industri musiman yang berkembang secara alamiah dan kurang ter- 
tangani secara serius. Semangat dan keinginan pemerintah untuk memperbaiki keadaan masa depan olahraga yang lebih baik, dilakukan melalui usaha membenahi seluruh komponen inti yang menopang kemajuan olahraga secara menyeluruh. Salah satu keseriusan pemerintah adalah dengan memberikan payung hukum yang lebih kuat melalui pemberlakuan Undangundang Nomor 3 tahun 2005 tentang Sistem Keolahragaan Nasional (SKN). Payung hukum tersebut juga mengatur tentang Industri Olahraga.

Permasalahan Industri Olahraga dalam Undang-undang Sistem Keolahragaan Nasional diatur dalam Bab XVI. Pengertian dan batasan Industri Olahraga adalah kegiatan bisnis bidang olahraga dalam bentuk produk barang dan/atau jasa. Setiap pelaksanaan industri olahraga yang dilakukan oleh Pemerintah, pemerintah daerah, dan/atau masyarakat wajib memperhatikan tujuan keolahragaan nasional serta prinsip penyelenggaraan kegiatan olahraga (pasal 78). Industri olahraga dapat berbentuk prasarana dan sarana yang diproduksi, diperjualbelikan, dan/atau disewakan untuk masyarakat (pasal 79 ayat 1 ).

Industri olahraga dapat berbentuk jasa penjualan kegiatan cabang olahraga sebagai produk utama yang dikemas secara profesional yang meliputi: Masyarakat yang melakukan usaha industri olahraga sebagaimana dimaksud pada ayat (1) dan ayat (2) dapat bermitra dengan Pemerintah, pemerintah daerah, organisasi olahraga dan/atau organisasi lain, baik dalam negeri maupun luar negeri (pasal 79 ayat 3). Dalam melaksanakan kemitraan sebagaimana dimaksud dalam ayat (3) masyarakat membentuk badan usaha sesuai dengan peraturan perundang-undangan (pasal 79 ayat 4).

Masyarakat yang melakukan usaha industri jasa olahraga memperhatikan kesejahteraan pelaku olahraga dan kemajuan olahraga.(pasal 79 ayat 5). Pembinaan dan pengembangan industri olahraga dilaksanakan melalui kemitraan yang saling menguntungkan agar terwujud kegiatan olahraga yang mandiri dan profesional (pasal 80 ayat 1). Pemerintah dan/atau pemerintah daerah memberikan kemudahan pembentukan sentra-sentra pembinaan dan pe- ngembangan industri olahraga. (pasal 80 ayat 2). Pemerintah dan/atau pemerintah daerah memfasilitasi pewujudan kemitraan pelaku industri olahraga dengan media massa dan media lainnya (pasal 80 ayat 3 ).

Dampak industri olahraga ke depan seharusnya tidak sebatas pada upaya untuk mencukupi dimensi internal keolahragaan, melainkan diharapkan lebih menggeliatkan serta memperbaiki harkat dan martabat masyarakat secara keseluruhan. Kemajuan Industri olahraga tidak hanya dinikmati oleh kalangan industri dan komunitas atau insan-insan olahraga semata, melainkan diharapkan manfaatnya merambah sampai ke masyarakat secara luas. Industri olahraga merupakan bagian dari upaya pemberdayaan masyarakat dan pembangunan masyarakat. Oleh karena itu tidaklah berlebihan manakala potensi industri olahraga jika digali dan dikembangkan, dapat menjadi sebuah solusi bagi upaya pengentasan kemiskinan dan persoalan pengangguran. Ada apa dengan kemiskinan dan pengangguran?

Kemiskinan dan pengangguran merupakan sebuah kompleksitas yang senantiasa menjadi persoalan bangsa-bangsa di dunia ini, terlebih lagi di negara yang sedang berkembang, seperti di Indonesia. Pertumbuhan jumlah penduduk tidak sebanding dengan kesempatan kerja yang tersedia. Akhirnya jumlah pengangguran semakin meningkat dan jumlah penduduk miskin juga semakin bertambah. Kondisi tersebut semakin diperparah dengan belum membaiknya krisis dan belum stabilnya ekonomi makro, yang mengakibatkan banyak orang kehilangan pekerjaan sebagai korban dari Pemutusan Hubungan Kerja (PHK).

Masalah kemiskinan dan pengangguran tetap akan menghantui Indonesia untuk lima tahun yang akan datang. Paling banyak bisa diciptakan situasi serta kondisi di mana orang mempunyai harapan. Pada waktu ini maka harapan ini pun masih langka. Nyatanya, beberapa pengukuran consumers index, dari Bank Indonesia dan lainnya, masih di bawah 100, artinya, harapan serba mineur. (M. Sadli, Business News, Senin 8 Agustus 2005).

Berdasarkan catatan dari berbagai sumber, jumlah penduduk miskin di Indonesia adalah 
sebesar 15 persen pada tahun 2005, sedangkan akhir tahun 2006, penduduk miskin di Indonesia sebesar 13,3 persen (Nurhadi, 2007). Secara proporsional prosentasenya mungkin menurun namun secara absolut- kuantitatif, jumlah penduduk miskin di Indonesia kemungkinan tidak berkurang. Bagaimana dengan angka pengangguran?

Angka pengangguran pemuda secara nasional adalah sebesar 16,7 persen. Secara nasional angka penggangguran laki-laki sebesar 13,9 persen, sedangkan pengangguran perempuan sebesar 21,3 persen. Angka pengangguran di perkotaan lebih besar daripada di desa. Pengangguran di perkotaan sebesar 20,7 persen dan penggangguran di pedesaan 13,6 persen. (Data Kemenegpora dan BPS, 2006).

Kebangkitan industri olahraga haruslah mengarah pada ikhtiar nyata dari bagian yang tak terpisahkan dari upaya mengentaskan kemiskinan dan mengatasi pengangguran di Indonesia. Model kemitraan perlu dijalin dan langkah-langkah koordinatif harus ditempuh untuk menggali potensi, meningkatkan kemampuan serta peluang bagi perkembangan industri olahraga. Industri olahraga merupakan bagian integral dari industri nasional dalam membuka lapangan kerja serta peluang usaha. Prinsip yang perlu dikembangkan adalah: mulai dari hal yang kecil, mulai dari solusi sederhana, dan mulai dari sekarang!.

Industri olahraga didefinisikan oleh Pitts, Fielding dan Miller sebagai "semua produksi barang, jasa, tempat, orang-orang, dan pemikiran yang ditawarkan kepada pelanggan, yang berkaitan dengan olahraga. (Pitts, Fielding, and Miller, 1994).Ozanian mengatakan bahwa; “Olahraga tidak hanya bisnis besar saja. Olahraga adalah salah satu dari industri yang tercepat bertumbuh-kembangnya di Amerika, dan adalah yang jalin menjalin dengan setiap aspek ekonomi - dari media dan pakaian sampai pada makanan dan periklanan ............. olahraga ada dimana-mana, dibarengi dengan suatu bunyi dering mesin kasir uang yang tak putus-putusnya" (Onzanian, 1995).

Klasifikasi Industri: (1) Pertanian, kehutanan dan perikanan; (2) Industri tambang; (3) Industri kepabrikan (manufacturing); (4) Industri konstruksi; (5) Industri transportasi, komunikasi; (6) Industri perdagangan (trade); (7) Industri finance (perbank-an); (8) Industri jasa (service); (9) Industri pemerintah (Encyclopedia Americana, 1975).

Kondisi Industri yang memiliki peluang untuk dikembangkan di Indonesia menurut Harsuki (2007) adalah meliputi: (1) Industri barang olahraga (sporting goods industry); (2) Olahraga amatir (yang dibawah KOI /KONI dan Induk organisasi cabang olahraga); (3) Olahraga profesional (Tinju, Golf, Balap mobil \& motor); (4) Kompleks olahraga ( Gelora Bung Karno, Gelanggang rekreasi Jaya Ancol); (5) Sponsor berbadan hukum; yang telah banyak mendanai kegiatan olahraga; (6) Media berita olahraga baik cetak maupun penyiaran.

Dari data Departemen Perindustrian tahun 1999 diperoleh data posisi industri alat olahraga (Departemen Perindustrian tidak menggunakan istilah industri barang olahraga melainkan alat olahraga) sebagai berikut: Jumlah perusahaan industri alat olahraga: 49 perusahaan, meliputi skala besar, menengah dan kecil. Sumatera Utara 1, Lampung 1, DKI 8, Jawa Barat 12, Jawa Tengah 11, Jawa Timur 12, D.I. Yogyakarta 3, dan Sulawesi Selatan 1. Investasi yang tertanam Rp120 milyar rupiah. Tenaga kerja yang terserap sekitar 5000 orang, tidak termasuk tenaga musiman. Jenis dan kapasitas produksi: Bola Tenis lapangan 54.040.000 buah; Bola sepak 3 . 837.000 buah; Bola voli 2.987.000 buah; Bola basket 3.523.000 buah; Bulu tangkis 17.635.000 buah; Lain-lain 1.000 .000 buah. Raket tenis dan bulu tangkis 707.000 buah; Stick golf 100.000 buah. Senar raket 240.000 buah; Meja billiard 130 buah; Meja Snooker 85 buah; Rel pancing 50.000 buah; Meja pingpong 3.000 buah; Peralatan hockey 1.500 set; Sport protective eqpmt: 5.000 .000 buah; Fibre matres 1.000 ton. Ekspor alat olahraga tahun 1997 U.S. $\$ 36,954,462$ Impor alat olahraga tahun 1997 U.S. \$9,523,981 (DitJen Industri Logam Mesin, Elektronika dan Aneka, 1999; sebagaimana dalam Harsuki, 2007).

Kedua pendekatan tersebut ditopang oleh empat pilar utama, yaitu (1) penciptaan kesempatan, (2) pemberdayaan masyarakat, (3) peningkatan kemampuan, dan (4) perlindungan 
sosial. Kedua pendekatan dan keempat pilar tersebut bertumpu pada perencanaan, penganggaran APBN dan APBD serta perbankan/lembaga keuangan non-bank, swasta dan masyarakat. Penanggulangan kemiskinan dan pengangguran harus dilakukan secara bersama-sama dan saling sinergi antara level nasional dan daerah. Pada level nasional, maka antara pemerintah pusat melalui departemen/LPND dan DPR, dunia usaha dan masyarakat/NGO/PT harus bahu-membahu dengan memobilisasi sumberdaya dan otoritas secara seimbang. Demikian pula pada level daerah, maka pemerintah daerah melalui dinas-dinas dan DPRD, dunia usaha lokal, masyarakat miskin/masyarakat luas/NGO/PT juga harus bahu membahu dengan memobilisasi sumberdaya dan otoritas secara seimbang. Kedua level tersebut harus secara sinergis menanggulangi kemiskinan pada levelnya.

Kebaharuan penelitian yang dilaksanakan terkait dengan permaslahan vital dan aktual yang diangkat dan dipilih, yaitu: (1) permasalahan Pengentasan Kemiskinan atau poverty Alleviation, dan (2) pengembangan industri olahraga. Proses pembangunan suatu bangsa selalu terkait dengan peningkatan kesejahteraan bagi seluruh masyarakat. Pengentasan kemiskinan (poverty Allevation) merupakan bagian yang tidak terpisahkan dengan usaha pemerintah dalam mensejahterakan masyarakat tersebut. Penanggulangan kemiskinan di Indonesia telah dipolakan melalui suatu strategi yang disebut dengan Strategi Nasional Penanggulangan Kemiskinan (SNPK). Strategi tersebut memiliki sasaran sebagai berikut: (1) berkurangnya penduduk miskin dari sebesar 15 persen pada tahun 2005 menjadi 13,3 persen pada akhir tahun 2006, pengurangan ini akan terus dilakukan pada tahun-tahun berikutnya, dan (2) terwujudnya percepatan pembangunan ekonomi di wilayah perbatasan, serta pulaupulau terpencil dan terisolir.

Pengentasan kemiskinan dapat dilakukan melalui pendekatan, yaitu (1) pendekatan peningkatan pendapatan, dan (2) pengurangan beban. Kedua pendekatan tersebut ditopang oleh empat pilar utama, yaitu (1) penciptaan kesempatan, (2) pemberdayaan masyarakat, (3) peningkatan kemampuan, dan (4) perlindungan sosial. Kedua pendekatan dan keempat pilar tersebut bertumpu pada perencanaan, penganggaran APBN dan APBD serta perbankan/lembaga keuangan non-bank, swasta dan masyarakat. Dalam Tataran Global, pengentasan kemiskinan juga menjadi agenda utama Negara-negara anggota $\mathrm{PBB}$, dengan cara mengadopsi Tujuan Pembangunan Milenium (Millennium Developments Goals /MDGs).

Mengacu pada latar belakang masalah yang telah dideskripsikan tersebut, akhirnya dapat diformulasikan rumusan masalah. Hibah Penelitian Strategis Nasional ini dilakukan untuk menjawab berbagai persoalan yang mendasar terkait dengan: (1) bagaimanakah penajaman aspek pragmatis industri olahraga yang harus dilakukan dalam program pengentasan kemiskinan, khususnya dari sisi pandangan pelaku usaha kecil, menengah, dan mikro?; (2) bagaimanakah perbaikan bentuk dan arah kebijakan publik pengembangan industri olahraga ke depan, agar lebih relevan dan memiliki nilai solusif, terutama untuk mengentaskan kemiskinan?; (3) Apa yang dapat dilakukan terkait dengan pengembangan substansi Matakuliah Kewirausahaan industri olahraga yang lebih aktual dan komprehensif?, dan (4) bagaimanakah peta jejaring home industri olahraga terutama pada tataran domestik?

Hasil kegiatan penelitian jika diterapkan akan memberikan manfaat, terutama untuk: (1) Memperoleh temuan-temuan penelitian secara faktual-empirik yang dapat menyelesaikan masalah masyarakat dan bangsa, terutama dalam aspek: Pengentasan kemiskinan melalui optimalisasi peran home industry olahraga; (2) Memberikan sumbangan langsung terhadap IKK sebagaimana dimaksud dalam RENSTRA; (3) Memberikan peluang yang lebih tinggi bahwa kualitas dan Kompetensi dosen Tim Pelaksana kegiatan akan lebih baik; (4) Dapat meningkatkan kualitas materi perkuliahan dengan adanya pengayaan dengan cara dimasukkannya hasilhasil penelitian sebagai materi bahan ajar; dalam hal ini untuk meningkatkan relevansi dan keluasan cakupan materi Matakuliah Kewirausahaan Industri Olahraga; (5) Mendorong perguruan tinggi untuk dapat memanfaatkan 
fasilitas dosen dan laboratorium selain untuk proses pembelajaran dapat dimanfaatkan untuk penelitian yang dapat berguna bagi negara dan bangsa.

\section{METODE PENELITIAN}

Metode penelitian yang ditempuh berupa penelitian deskriptif dengan menggunakan pendekatan survei. Survei bertujuan untuk mendeskripsikan secara faktual tentang berbagai respon aktual para pelaku sektor riil industri mikro olahraga. Respon yang diungkap terkait dengan aspek faktual yang berhubungan dengan berbagai indikator dimensi penguatan kebijakan publik usaha mikro industri olahraga. Dimensi yang diungkap berkaitan dengan penumbuhan iklim usaha yang selama ini dilakukan oleh Pemerintah maupun Pemerintah Daerah, terutama untuk pengentasan kemiskinan. Dimensi tersebut meliputi: (1) pendanaan, (2) sarana dan prasarana, (3) informasi usaha, (4) kemitraan, (5) perizinan usaha, (6) kesempatan berusaha, (7) promosi dagang, (8) dukungan kelembagaan. Bentuk penguatan kebijakan publik dalam hal penumbuhan iklim usaha, mendasarkan pada konfigurasi respon tentang kepuasan pelaku usaha industri mikro olahraga atas kebijakan-kebijakan riil decision maker.

Di samping survei tersebut, sesuai dengan skim pendanaan riset yang dilakukan, maka penelitian ini juga diarahkan untuk menghasilkan produk atau luaran tertentu. Luaran berupa: (1) kumpulan publikasi ilmiah di jurnal terakreditasi; (2) kemanfaatan teknologi tepat guna dan/atau rekayasa sosial/rumusan kebijakan publik; (3) naskah atau Buku Ajar yang berupa draft, dan (4) berkembangnya jejaring kerja sama antarpeneliti, antarpelaksanaan kegiatan dan antarlembaga.

Survei dilakukan pada beberapa kota/kabupaten terpilih di Provinsi Jawa Barat, Jawa Tengah, dan Jawa Timur. Penentuan wilayah ini merupakan bentuk sampling area yang dikembangkan secara purposif sampling dan mengacu pada pertimbangan memilih kantung-kantung industri olahraga di wilayah tertentu. Berdasarkan pertimbangan tersebut, akhirnya ter- pilih beberapa kota/kabupaten di ketiga provinsi tersebut, yaitu: Majalengka (Jawa Barat), Solo (Jawa Tengah), Karanganyar (Jawa Tengah), Sukoharjo (Jawa Tengah), Nganjuk (Jawa Timur), Ponorogo (Jawa Timur), dan Madiun (Jawa Timur). Definisi operasional berkenaan dengan definisi tentang: (1) Industri olahraga, (2) Usaha Mikro, (3) kemiskinan, dan (4) pengentasan kemiskinan.

Definisi operasional berkenaan dengan definisi tentang: (1) Industri olahraga, (2) Usaha Mikro, (3) kemiskinan, dan (4) pengentasan kemiskinan. Industri olahraga adalah semua produksi barang, jasa, tempat, orang-orang, dan pemikiran yang ditawarkan kepada pelanggan, yang berkaitan dengan olahraga. Industri Olahraga adalah kegiatan bisnis bidang olahraga dalam bentuk produk barang dan/atau jasa; Usaha Mikro adalah usaha produktif milik orang perorangan dan/atau badan usaha perorangan yang memenuhi kriteria Usaha Mikro, yaitu: memiliki kekayaan bersih paling banyak Rp50.000.000,- (lima puluh juta rupiah) tidak termasuk tanah dan bangunan, memiliki hasil penjualan tahunan paling banyak Rp300.000.000,- (tiga ratus juta rupiah); Kemiskinan adalah ketidakmampuan individu dalam memenuhi kebutuhan dasar minimal untuk dapat hidup layak; Pengentasan kemiskinan (poverty Allevation) merupakan bagian yang tidak terpisahkan dengan usaha pemerintah dalam mensejahterakan masyarakat.

Instrumen penelitian dikembangkan sesuai dengan kebutuhan survei. Pengembangan instrumen telah dilakukan secara bertahap dengan mengacu pada dimensi-dimensi penguatan kebijakan publik pada sektor industri mikro olahraga. Angket dikonstruksikan sesederhana mungkin tapi diarahkan pada fungsi untuk mengungkap butir-butir penting dan valid tentang variabel yang diungkap dalam penelitian. Konstruksi sederhana dari sebuah angket diperlukan agar pelaku sektor riil industri mikro olahraga dapat secara efektif merespon persoalan faktual yang akan diungkap oleh peneliti.

\section{HASIL DAN PEMBAHASAN}

\section{Hasil Penelitian}


Data yang didesk nai respon kepuas merupakan penil terhadap "kinerja membangun iklin raga. Penilaian be usaha atas layanc tiap-tiap dimensi (2) sarana dan pr (4) kemitraan, (5) patan berusaha, kungan kelembag

Pendeskripsic pelaku usaha ind kan menurut wi yakni meliputi: (1 vinsi Jawa Tengah, dan (3) Provinsi Jawa Timur. Rekapitulasi hasil survei diuraikan secara

ijadikan blik Peılam hal tri olahpelaku nsi Jawa in seba-

ijadikan blik PeIlam hal tri olahpelaku usaha industri mikro olahraga di Provinsi Jawa

Tabel 1. Respon Kepuasan Pelaku Usaha untuk Tiap Dimensi Iklim Usaha Industri Mikro Olahraga di Provinsi Jawa Barat $(n=37)$

\begin{tabular}{|c|c|c|c|c|c|c|c|}
\hline \multirow{2}{*}{ No } & \multirow{2}{*}{ Dimensi Iklim Usaha } & \multicolumn{5}{|c|}{ Konfigurasi Respon } & \multirow{2}{*}{ Jumlah } \\
\hline & & KS & $\mathbf{K}$ & C & B & BS & \\
\hline 1 & Pendanaan & & 10 & 20 & 7 & & 37 \\
\hline 2 & Sarana dan Prasarana & & 17 & 18 & 2 & 5 & 37 \\
\hline 3 & Informasi Usaha & & 12 & 22 & 3 & & 37 \\
\hline 4 & Kemitraan & & 5 & 24 & 6 & 2 & 37 \\
\hline 5 & Perizinan Usaha & & 4 & 30 & 3 & & 37 \\
\hline 6 & Kesempatan Berusaha & & 3 & 32 & 1 & 1 & 37 \\
\hline 7 & Promosi Dagang & & & 20 & 12 & 5 & 37 \\
\hline 8 & Dukungan Kelembagaan & & & 18 & 17 & 7 & 37 \\
\hline
\end{tabular}

Keterangan: KS adalah Kurang Sekali, K adalah Kurang, C adalah Cukup, B adalah Baik, BS adalah Baik Sekali

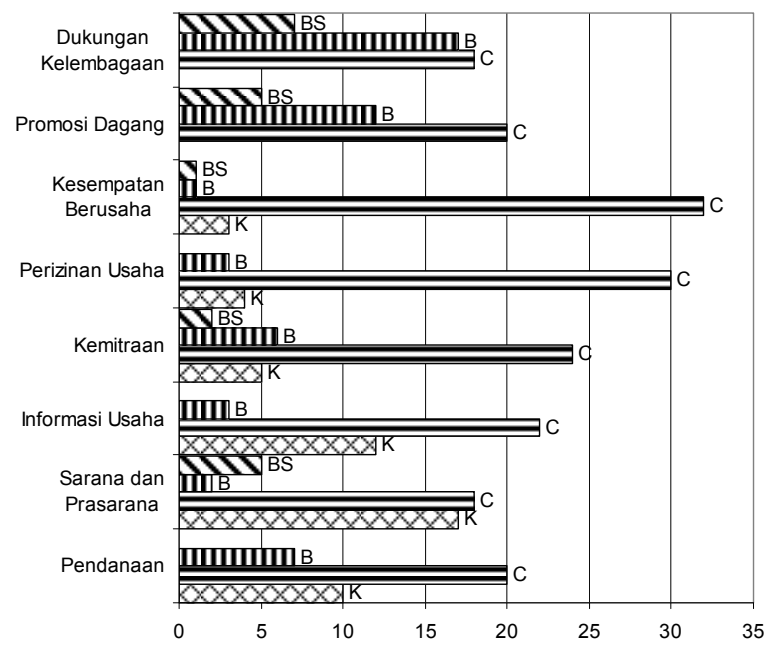

Gambar 1. Konfigurasi Respon Kepuasan Pelaku Usaha Mikro Industri Olahraga di Jawa Barat 
Tabel 2. Respon Kepuasan Pelaku Usaha untuk Tiap Dimensi Iklim Usaha Industri Mikro Olahraga di Provinsi Jawa Tengah $(n=48)$

\begin{tabular}{|c|c|c|c|c|c|c|c|}
\hline \multirow{2}{*}{ No } & \multirow{2}{*}{ Dimensi Iklim Usaha } & \multicolumn{5}{|c|}{ Konfigurasi Respon } & \multirow{2}{*}{ Jumlah } \\
\hline & & KS & $\mathbf{K}$ & $\mathrm{C}$ & B & BS & \\
\hline 1 & Pendanaan & & 15 & 31 & 5 & 5 & 48 \\
\hline 2 & Sarana dan Prasarana & & 3 & 10 & 30 & 15 & 48 \\
\hline 3 & Informasi Usaha & & & 8 & 35 & 5 & 48 \\
\hline 4 & Kemitraan & & & 5 & 25 & 18 & 48 \\
\hline 5 & Perizinan Usaha & & & 8 & 35 & 5 & 48 \\
\hline 6 & Kesempatan Berusaha & & & 18 & 28 & 2 & 48 \\
\hline 7 & Promosi Dagang & & & 6 & 40 & 2 & 48 \\
\hline 8 & Dukungan Kelembagaan & & & 1 & 32 & 15 & 48 \\
\hline
\end{tabular}

Keterangan: KS adalah Kurang Sekali, K adalah Kurang, C adalah Cukup, B adalah Baik, BS adalah Baik Sekali

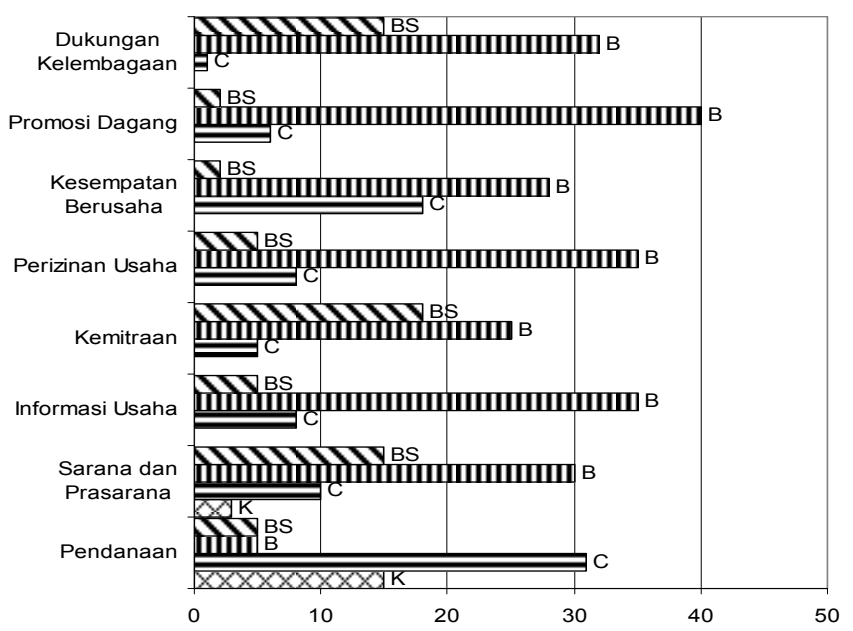

Gamhar? Konfiouraci Recnon Pelak11 I Jcaha Mikrn Ind11stri Olahraoa di Jawa Tengah

\section{1) Provinsi Jawa Barat (Majalengka)}

Hasil analisis profil industri olahraga di Majalengka khususnya di PT Sinjaraga Santika Sport, yang mempoduksi bola sepak, bola basket, dan bola volley, maka dapat diperoleh uat, bahwa kegiatan nemberikan lapangan pekerja. Penghasilan Rp500.000,- sampai bulannya. Rata-rata adalah 3 orang. Dean pekerja di industri minimal. Salah satu adalah bahwa kesetaistri tersebut sangan rjakan pekerja pria dan pekerja wanita 84 perbandingan yang lumayan proporsional. Hal ini dapat dijadikan sebuah rujukan tentang kepeloporan industri mikro olahraga dalam kaitannya dengan program pengarusutamaan kesetaraan gender. 
Tabel 3. Respon Kepuasan Pelaku Usaha untuk Tiap Dimensi Iklim Usaha Industri Mikro Olahraga di Provinsi Jawa Timur $(n=42)$

\begin{tabular}{|c|c|c|c|c|c|c|c|}
\hline \multirow{2}{*}{ No } & \multirow{2}{*}{ Dimensi Iklim Usaha } & \multicolumn{5}{|c|}{ Konfigurasi Respon } & \multirow{2}{*}{ Jumlah } \\
\hline & & KS & $\mathbf{K}$ & $\mathrm{C}$ & B & BS & \\
\hline 1 & Pendanaan & & & 4 & 26 & 12 & 42 \\
\hline 2 & Sarana dan Prasarana & & & 6 & 25 & 11 & 42 \\
\hline 3 & Informasi Usaha & & & 12 & 22 & 8 & 42 \\
\hline 4 & Kemitraan & & & 12 & 20 & 10 & 42 \\
\hline 5 & Perizinan Usaha & & & 8 & 26 & 8 & 42 \\
\hline 6 & Kesempatan Berusaha & & & 11 & 22 & 9 & 42 \\
\hline 7 & Promosi Dagang & & & 8 & 30 & 4 & 42 \\
\hline 8 & Dukungan Kelembagaan & & & 8 & 27 & 7 & 42 \\
\hline
\end{tabular}

Keterangan: KS adalah Kurang Sekali, K adalah Kurang, C adalah Cukup, B adalah Baik, BS adalah Baik Sekali

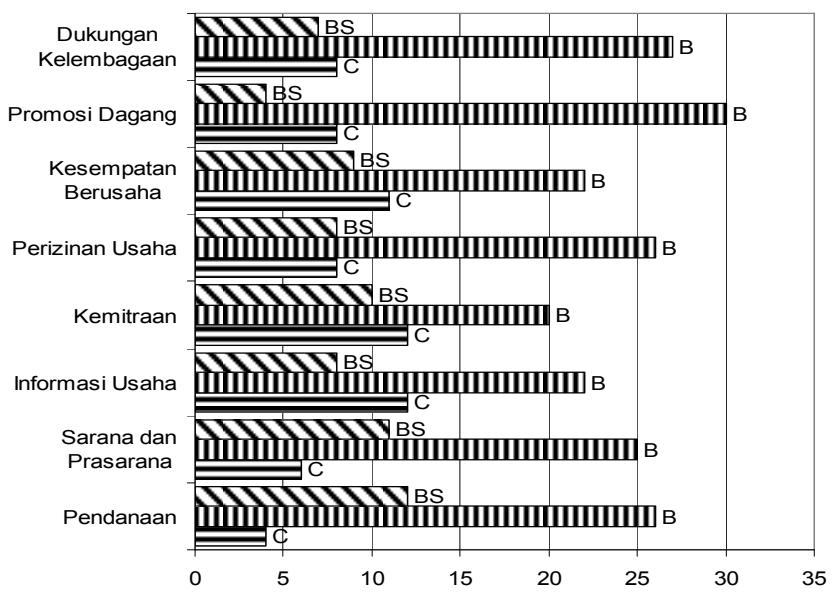

Gambar 3. Konfigurasi Respon Kepuasan Pelaku Usaha Mikro Industri Olahraga di Jawa Timur

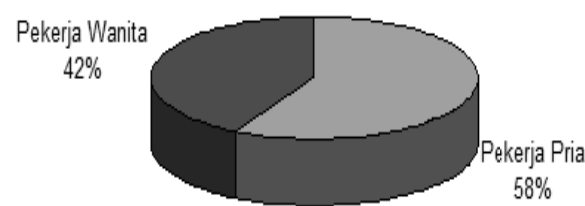

Gambar 4. Komparasi Pekerja Industri Mikro Olahraga berdasarkan Faktor Jenis Kelamin di Majalengka

2) Provinsi Jawa Tengah (Solo, Sukoharjo, dan Karanganyar)

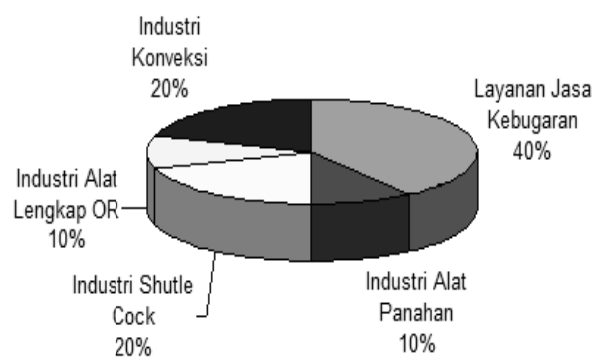

Gambar 5. Komposisi Jenis Industri Mikro Olahraga di Solo
Jumlah pekerja industri mikro olahraga pada 10 industri olahraga yang disurvei adalah sejumlah 92 orang, dengan komposisi pekerja lakilaki sebanyak 69 orang (75 persen) dan pekerja perempuan sebanyak 23 orang (25 persen). Pada umumnya industri berupa industri perorangan dengan tenaga kerja berkualifikasi SLTA ke bawah. Khusus untuk jasa kebugaran, para instruktur sebagian besar berkualifikasi sarjana (S1), namun mereka berpenghasilan di bawah Rp1.000.000,- karena mereka umumnya bekerja free lance dan part time.

Bentuk Industri olahraga di Surakarta tetap dapat eksis, walaupun penghasilan rata-rata pekerja di bawah Rp1.000.000,- dengan tanggungan keluarga 3 orang. Beberapa industri perorangan atau home industry bahkan hanya mampu menggaji pekerjanya maksimal Rp500.000,-, karena gaji yang diberikan amat bergantung pada order atau pesanan. 


\section{SIMPULAN}

Berdasarkan analisis dan pembahasan tersebut di atas, maka simpulan hasil pembahasan dapat diuraikan sebagai berikut:

Kepuasan pelaku usaha mikro industri olahraga terhadap kinerja Pemerintah Daerah atas 8 (delapan) dimensi iklim usaha bervariasi. (1) Di Jawa Barat dimensi yang mendapat nilai positif meliputi: promosi dagang dan dukungan lembaga; (2) di Jawa Tengah; sarana dan prasarana, kemitraan, perizinan usaha, dan dukungan kelembagaan.; (3) di Jawa Timur, kepuasan pelaku usaha terjadi pada ke-delapan dimensi, yakni: pendanaan, sarana dan prasarana, informasi usaha, kemitraan, perizinan usaha, kesempatan berusaha, promosi dagang, dukungan kelembagaan.

Industri mikro olahraga merupakan upaya kolektif dari berbagai pihak untuk mengembangkan perilaku ekonomi antara produsen dan konsumen dengan dijembatani oleh bentuk-bentuk produksi barang atau jasa olahraga. Perilaku ekonomi tersebut berpotensi bagi upaya pengentasan kemiskinan dan penanggulangan pengangguran.

Profil industri barang dan atau jasa olahraga yang disurvei meliputi industri yang ada di Jawa Barat, Jawa Tengah, dan Jawa Timur. Kota yang disurvei meliputi: Majalengka, Solo, Sukoharjo, Karanganyar, Nganjuk, Madiun, dan Ponorogo. Jumlah yang disurvei di Jawa Barat sejumlah 1 industri yang mempekerjakan 100 orang; di Jawa Tengah sejumlah 10 industri barang dan jasa olahraga yang mempekerjakan sejumlah 92 orang; di Jawa Timur 6 industri pakaian dan peralatan olahraga yang mempekerjakan 102 orang.

Komposisi pekerja di sektor industri olahraga adalah: di Jawa Barat meliputi 58 persen pekerja laki-laki dan 42 persen pekerja perempuan; di Jawa Tengah, 75 persen pekerja lakilaki dan 25 persen pekerja perempuan; dan di Jawa Timur, pekerja laki-laki 62,7 persen dan 37,3 persen pekerja perempuan.

Penghasilan pekerja di industri barang dan jasa olahraga di Jawa Barat, Jawa Tengah, dan Jawa Timur sebagian besar adalah berkisar Rp500.000,- sampai dengan Rp1.000.000,- per bulan dengan tanggungan keluarga rata-rata 3 orang. Dengan fakta yang demikian, maka dapat dipahami bahwa secara riil bekerja di sektor industri belum bisa menjanjikan, apalagi banyak pekerja home industri olahraga yang digaji di bawah Rp500.000,- per bulan. Jadi, industri olahraga secara faktual sekedar memberikan lapangan pekerjaan sampingan bagi sebagian masyarakat, namun belum berdampak secara signifikans bagi pengentasan kemiskinan dan penanggulangan masalah pengangguran.

Rekomendasi. Rekomendasi yang dapat disampaikan dari hasil pengkajian tentang dampak industri olahraga terhadap pengentasan kemiskinan dan penanggulangan pengangguran adalah sebagai berikut:

Usaha Pemerintah Daerah untuk membangun iklim usaha industri mikro olahraga mencakup delapan dimensi belum semuanya memberikan kepuasan pada pelaku usaha. Pemerintah Daerah berusaha secara maksimal dengan melakukan pembenahan perbaikan mutu layanan pada dimensi yang masih lemah dan meningkatkan dan mempertahankan dimensi penguatan iklim usaha yang sudah bagus.

Industri olahraga adalah industri yang berpotensi besar untuk menggerakkan perilaku ekonomi masyarakat secara kolektif. Dengan demikian industri olahraga berpotensi sebagai sektor yang dapat memberikan dampak signifikan bagi pengentasan kemiskinan dan penanggulangan pengangguran. Industri olahraga sekarang baru merupakan "raksasa yang sedang tidur" yang perlu digugah melalui serangkaian kebijakan sistematis dari pemerintah pusat dan daerah, masyarakat, dan investor.

Pengentasan kemiskinan dan penanggulangan pengangguran dilakukan dengan cara meningkatkan kontribusi perintisan industri olahraga terhadap proses pertumbuhan ekonomi, baik secara lokal maupun makro. Terjadinya proses pengentasan kemiskinan dan penyediaan lapangan pekerjaan merupakan konsekwensi dari membaiknya pertumbuhan ekonomi lokal dan makro.

Kecenderungan (Trend) kebutuhan peralatan olahraga dan jasa olahraga produk/karya bangsa sendiri perlu terus digalakkan dalam rangka untuk memicu dan memacu kebutuhan 
dan perilaku pasar yang dapat memperbasar volume produk dan layanan jasa olahraga domestik.

Bimbingan teknis dan penyaluran modal khusus amat diperlukan oleh para pelaku usaha industri olahraga yang pada umumnya selama ini hanya "bermain" di sektor usaha kecil dan mikro dengan sirkulasi permodalan yang tidak signifikan untuk menggairahkan indikator perkonomian secara umum.

Kegiatan Pendidikan dan Latihan (Diklat) perlu terus dilakukan untuk memberikan visi, inovasi pemikiran, serta pengembangan kemampuan kewirausahaan olahraga yang lebih mumpuni, karena ke depan para pelaku usaha industri dan jasa olahraga harus memiliki daya saing yang tinggi. Mereka tidak boleh puas hanya dengan mempertahankan konsep usaha yang tradisional sebagaimana yang selama ini mereka lakukan sebagaimana yang dilakukan oleh pendahulu mereka. Zaman berubah, strategi usaha juga harus selalu menyesuaikan dengan perubahan-perubahan tersebut.

Perintisan pembangunan sentra industri olahraga perlu diupayakan di kantung-kantung wilayah yang berpotensial untuk pengembangan industri barang dan atau jasa olahraga. Perintisan tersebut dilengkapi dengan Research and Development $(R \mathcal{E} D)$, karena merintis sebuah industri apapun bukan sekadar mendirikan, melainkan juga terkait dengan aspek keberlangsungan (sustainable) dalam jangka panjang yang memerlukan perencanaan manajerial program yang baik untuk seluruh komponennya.

Peran serta perguruan tinggi dalam mengembangkan mutu dan kualitas industri mikro olahraga dapat dilakukan dengan berbagai cara-cara strategis. Setidak-tidaknya terdapat tiga hal yang dapat dilakukan yaitu: (1) melakukan riset-riset prioritas pengembangan industri mikro olahraga yang terkait dengan persoalan pengangkatan harkat dan martabat masyarakat menengah ke bawah, (2) melakukan publikasi ilmiah agar hasil penelitian dapat memberikan resonansi yang kuat bagi para peneliti lain maupun bagi para pengambil keputusan (decision maker) dan stake holder industri mikro olahraga, dan (3) matakuliah kewirausahaan yang diberikan kepada maha- siswa mengakomodasikan pada materi atau minat khusus pada pengembangan industri olahraga.

\section{DAFTAR PUSTAKA}

Kristiyanto, Agus. 2008. Sports Home Industry Development: a Descriptive Study on Response and Expectation of the Small-Scale Sports Industry Businessmen in Solo, Central Java, Indonesia. Proceeding. International Conference on Sport Industry. Bandung, October, 21 th-23 th 2008. (pp. 7384).

Sudijandoko, Andun. 2009. The Development and Preservation of Traditional Sport in Sport Industry Order. Proceeding, International Seminar of Physical Education and Sport, Semarang State University, April 28th-29 th, (pp. 39-52).

Pasaribu, Bomer. 2002. Puncak Krisis Ketenagakerjaan. Dalam http://www. nasio nal-m@polarhome.com. diakses tanggal 12 September 2009.

Departemen Pendidikan Nasional, 2003. Life Skills-Pendidikan Kecakapan Hidup. Jakarta: Depdiknas.

Dixon, John and Robert Scheurell. 1995. Social Security Programs: a Cross-Cultural Comparative Perspective. London: Greenwood Press.

Suharto, Edi. 2005. Membangun Masyarakat Memberdayakan Rakyat: Kajian Strategis Pembangunan Kesejahteraan Sosial dan Pekerjaan Sosial. Bandung: Refika Aditama.

Haryati, Eni. 2003. Pembangunan Masyarakat Desa dan Penanggulangan Kemiskinan. Disertasi Program Pascasarjana UGM Yogyakarta, tidak dipublikasi.

Notodihardjo, Hardjono. 2002. Pendidikan Tinggi dan Tenaga Kerja Tingkat Tinggi di Indonesia. Jakarta: UI Press.

Harsuki. 2007. Manajemen Sentra Industri Olahraga. Makalah. Yogyakarta: Universitas 
Negeri Yogyakarta.

Jenkins, M. 1993. Extending Social Security Protection to the Entire Population: Problem and Issues. International Journal of Social Security Review, 46 (2):3-20.

Harsono, Mugi. 2007. Operasionalisasi dan Perluasan Model Theory of Planned Behavior pada Kasus Perencanaan Suksesi Perusahaan Keluarga: Suatu Model Konseptual. Jurnal Manajemen Usahawan Indonesia No.09/TH.XXXVI (September): 45-55.

Harsono, Mugi. 2007. Pengembangan Model Konseptual tentang Keterkaitan Para Pelaku dengan Keluasan Rencana Suksesi Perusahaan Keluarga. Jurnal Benefit, 11 (1): 30-45.

Siregar, Namora. 2009. Sport and Development in Indonesia. Proceeding, International Seminar of Physical Education and Sport, Semarang State University, April, April 28th-29 th, (pp. 53 - 57).

Nurhadi. 2007. Mengembangkan Jaminan Sosial, Mengentaskan Kemiskinan. Yogyakarta: Media Wacana.

Penyajian Data Informasi Kementerian Negara Pemuda dan Olahraga Tahun 2006. Jakarta: Kementerian Negara Pemuda dan Olahraga dan Badan Pusat Statistika.

Ginting, Perdana. 2009. Perkembangan Industri Indonesia. Bandung: Yrama Widya.

Randy R. Wrihatnolo dan Riant Nugroho. 2006. Manajemen Pembangunan Indonesia. Jakarta: PT Elex Media Komputindo.
Satori. 2002. Implementasi Life Skills dalam Konteks Pendidikan di Sekolah. Jurnal Pendidikan dan Kebudayaan. Nomor 034, Januari 2002.

Swasono, Sri Edi. 2004. Memerangi Kemiskinan dan Pengangguran. Dalam http:// www. suarapembaruan.com/news/2004/9/22/ index.html. Diakses tanggal 12 September 2009.

Rasyid. Sudrajat. 2007. The National Policy of Sports Industry Development in Indonesia. Proceeding, International Conference on Sport Industry: The Development on Sport Industry, Promoting Marketing Strategy. Surakarta, September, 11th- 12th 2007 (pp. 3-6).

Undang-undang Republik Indonesia Nomor 3 Tahun 2005 Tentang Sistem Keolahragaan Nasional. Jakarta: Biro Humas dan Hukum Kementerian Negara Pemuda dan Olahraga Republik Indonesia.

Undang-undang Republik Indonesia Nomor 20 Tahun 2008 Tentang Usaha Mikro, Kecil, dan Menengah, Jakarta: Sinar Grafika, 2008.

Undang-undang Republik Indonesia Nomor 20 Tahun 2008 Tentang Usaha Mikro, Kecil, dan Menengah. Yogyakarta: Pustaka Yustisia, 2009.

Ruwiyanto, Wahyudi. 1994. Peranan Pendidikan dalam Pengentasan Masyarakat Miskin: Pendekatan Analisis Organisasi Secara Kuantitatif. Jakarta: Raja Grafindo Persada. 